\title{
Human umbilical cord tissue-derived mesenchymal stromal cells attenuate remodeling after myocardial infarction by proangiogenic, antiapoptotic, and endogenous cell-activation mechanisms
}

\author{
Diana Santos Nascimento ${ }^{1+}$, Diogo Mosqueira ${ }^{1+}$, Luís Moura Sousa $^{1,2}$, Mariana Teixeira $^{3}$, Mariana Filipe ${ }^{3}$, \\ Tatiana Pinho Resende ${ }^{1}$, Ana Francisca Araújo ${ }^{1,4}$, Mariana Valente ${ }^{1,2}$, Joana Almeida ${ }^{3}$, José Paulo Martins ${ }^{3}$, \\ Jorge Miguel Santos ${ }^{3}$, Rita Nogueira Bárcia ${ }^{3}$, Pedro Cruz ${ }^{3}$, Helder $\mathrm{Cruz}^{3}$ and Perpétua Pinto-do-Ó ${ }^{1,2^{*}}$
}

\begin{abstract}
Introduction: Among the plethora of cells under investigation to restore a functional myocardium, mesenchymal stromal cells (MSCs) have been granted considerable interest. However, whereas the beneficial effects of bone marrow MSCs (BM-MSCs) in the context of the diseased heart are widely reported, data are still scarce on MSCs from the umbilical cord matrix (UCM-MSCs). Herein we report on the effect of UCM-MSC transplantation to the infarcted murine heart, seconded by the dissection of the molecular mechanisms at play.

Methods: Human umbilical cord tissue-derived MSCs (UCX $\left.{ }^{\circledast}\right)$, obtained by using a proprietary technology developed by ECBio, were delivered via intramyocardial injection to C57BL/6 females subjected to permanent ligation of the left descending coronary artery. Moreover, medium produced by cultured UCX ${ }^{\circledR}$ preconditioned under normoxia $(\mathrm{CM})$ or hypoxia $(\mathrm{CMH})$ was collected for subsequent in vitro assays.
\end{abstract}

Results: Evaluation of the effects upon intramyocardial transplantation shows that UCX ${ }^{\circledR}$ preserved cardiac function and attenuated cardiac remodeling subsequent to myocardial infarction (MI). UCX further led to increased capillary density and decreased apoptosis in the injured tissue. In vitro, UCX ${ }^{-}$-conditioned medium displayed (a) proangiogenic activity by promoting the formation of capillary-like structures by human umbilical vein endothelial cells (HUVECs), and (b) antiapoptotic activity in HL-1 cardiomyocytes subjected to hypoxia. Moreover, in adult murine cardiac Sca- $1^{+}$progenitor cells (CPCs), conditioned medium enhanced mitogenic activity while activating a gene program characteristic of cardiomyogenic differentiation.

Conclusions: UCX ${ }^{\circledast}$ preserve cardiac function after intramyocardial transplantation in a MI murine model. The cardioprotective effects of $U C X^{\circledR}$ were attributed to paracrine mechanisms that appear to enhance angiogenesis, limit the extent of the apoptosis, augment proliferation, and activate a pool of resident CPCs. Overall, these results suggest that UCX ${ }^{\circledR}$ should be considered an alternative cell source when designing new therapeutic approaches to treat Ml.

\footnotetext{
* Correspondence: perpetua@ineb.up.pt

${ }^{\dagger}$ Equal contributors

'INEB, Instituto de Engenharia Biomédica, Universidade of Porto, Rua do

Campo Alegre, 823, 4150-180 Porto, Portugal

${ }^{2}$ ICBAS, Instituto de Ciências Biomédicas Abel Salazar, Universidade of Porto,

Porto, Portugal

Full list of author information is available at the end of the article
}

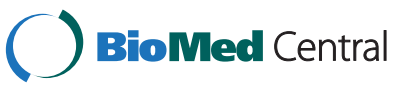

(c) 2014 Nascimento et al.; licensee BioMed Central Ltd. This is an Open Access article distributed under the terms of the Creative Commons Attribution License (http://creativecommons.org/licenses/by/2.0), which permits unrestricted use, distribution, and reproduction in any medium, provided the original work is properly cited. The Creative Commons Public Domain Dedication waiver (http://creativecommons.org/publicdomain/zero/1.0/) applies to the data made available in this article, unless otherwise stated. 


\section{Introduction}

Cardiac diseases, in particular, ischemic heart disease, represent a major cause of mortality and morbidity worldwide, imposing a heavy economic burden on highand middle-income countries [1]. Myocardial infarction (MI) is characterized by extensive cardiomyocyte death and functional degradation of the cardiac tissue downstream from a coronary occlusion. After infarction, a cascade of dramatic biochemical and morphologic events, collectively designated cardiac remodeling, is initiated. These events culminate in the formation of a nonfunctional scar in place of the damaged myocardium. Currently, no therapeutic solutions are available for replacing the net loss of contractile tissue by new cardiomyocytes. The only efficient long-term treatment is heart transplant, which is impaired mainly by the shortage of organ donors and the requirement for immunosuppression [2]. Consequently, cell therapies aimed at directing heart's response toward a more-efficient repair and/or myocardial regeneration have received considerable attention in the last decade [3].

The potential for cardiac regeneration or, at the least, for improving the myocardial repair process, is under investigation for a plethora of different adult and embryonic-derived cell populations [4]. Mesenchymal stromal cells (MSCs) have taken special prominence because of their immunomodulatory role, which enables major histocompatibility complex-mismatched allogeneic transplantation [5]. Although originally harvested from the bone marrow [6,7], MSC-like cells have also been identified in different tissues, and the most common sources are adipose tissue [8] and umbilical cord tissue [9]. The use of allogeneic umbilical cord tissue, namely umbilical cord matrix (Wharton's jelly), is advantageous in comparison to any other source or because of (a) the extraction process, i.e. absence of invasiveness and higher efficiency, (b) higher MSCs cell yield [10], and (c) the shorter MSCs doubling time, enabling a faster attainment of the abundant cell numbers required for clinical use $[11,12]$ while maintaining a safe profile.

Furthermore, we recently showed that $\mathrm{UCX}^{\circ}$ were more potent modulators of the immune system than bone marrow-derived MSCs (BM-MSCs), being able to repress T-cell activation and promote the expansion of regulatory $\mathrm{T}$ cells more efficiently [13].

It has been extensively demonstrated that BM-MSCs can be harnessed for cardiac repair [14-18], with clinical trials showing promising results [19]. Several preclinical studies have demonstrated the improvement of heart function and the reduction of infarct size after MSCs transplantation [20-25]. The cardioprotective mechanisms exerted by MSCs appear to encompass (a) transdifferentiation/fusion events [26-29], (b) attenuation of cardiac remodeling [20,30-32], and (c) enhancement of angiogenesis [25,33-35]. These appear to occur via cellular engraftment into the host myocardium [36] and/or by a paracrine action (that is, favoring cardiac repair by MSCs-secreted factors) [37]. MSCs are frequently regarded as factories of cytokines and growth factors $[38,39]$ whose production is often increased under hypoxic conditions [35]. The paracrine action of MSCs in the context of MI has been demonstrated by the recapitulation of the cardioprotective effects attained by cell transplantation through administration of the conditioned medium produced in vitro by the same cells [40].

Although the beneficial effects of BM-MSCs in the context of the diseased heart have been extensively reported, data are still scarce on the effect of MSCs from the umbilical cord tissue (UCM-MSC) [23,41-44]. Thus, we set out to investigate the effect of transplantation of a well-defined umbilical cord tissue-derived cellular product $\left(\mathrm{UCX}^{\circ}\right)$ on the heart of myocardial infarcted mice, seconded by the dissection of the molecular mechanisms at play.

In this study, a specific population of human stem cells derived from the umbilical cord tissue (Wharton's jelly), hereafter designated $\mathrm{UCX}^{\circ}$, was isolated, expanded, and cryopreserved on the basis of proprietary technology developed within our team [43]. We show that $\mathrm{UCX}^{\circ}$ delivery into the myocardium of mice subjected to left anterior descending (LAD) coronary artery ligation (a) preserves heart function, (b) attenuates the cardiac remodeling process, (c) increases capillary density, and (d) prevents apoptosis in the infarcted tissue. Moreover, in vitro, we demonstrated that $\mathrm{UCX}^{\bullet}$ exerts a beneficial effect on different cellular components of the myocardium through paracrine mechanisms. Hence, $\mathrm{UCX}^{\circ}$ protect cardiomyocytes from hypoxia-induced apoptosis, enhance the formation of capillary-like structures by endothelial cells, and trigger the differentiation of Sca- $1^{+}$ adult cardiac progenitor cells (CPCs) [45].

\section{Material and methods}

\section{Ethics and regulation}

This study was approved by the Ethics Committee at the Cascais Hospital Dr. José de Almeida, in the scope of a research protocol between ECBio-Research \& Development in Biotechnology, S.A., and HPP Saúde-Parcerias Cascais, S.A. In addition, all experimental research was in compliance with the Helsinki Declaration. Umbilical cord donations were obtained with written informed consents, according to Directive 2004/23/EC, which sets the standards of quality and safety for the donation, procurement, testing, processing, preservation, storage, and distribution of human tissues and cells [46]. All the animal-testing procedures were subjected to approval by the IBMC-INEB (Instituto de Biologia Molecular e Celular-Instituto de Engenharia Biomédica) Animal Ethics 
Committee, and to the Direcção Geral de Veterinária (permit 022793), and are in conformity with the Directive 2010/63/EU of the European Parliament [47]. Humane end points were followed in accordance to the OECD Guidance Document on the Recognition, Assessment, and Use of Clinical Signs as Humane End points for Experimental Animals Used in Safety Evaluation [48].

\section{$\mathrm{UCX}{ }^{\circledR}$ isolation and ex vivo maintenance}

Human $\mathrm{UCX}^{\circ}$ were isolated according to [13] and patented proprietary technology [44] developed by ECBio. In brief, fresh human umbilical cords were obtained after term natural or $\mathrm{C}$-section births, transported to the laboratory facilities in a sterile container, and processed within 48 hours. The procedure includes three recovery phases to ensure a high cell yield and high isolation success rates.

Isolated UCX ${ }^{\circ}$ were cultured (up to P7) in Minimum Essential Medium $\alpha$ ( $\alpha$-MEM; Gibco, Carlsbad, CA, USA), $1 \% \mathrm{P} / \mathrm{S}(100 \mathrm{U} / \mathrm{ml}$ Penicillin and $100 \mu \mathrm{g} / \mathrm{ml}$ Streptomycin, Labclinics, Barcelona, Spain), buffered with $10 \mathrm{mM}$ HEPES (Gibco), hereafter designated Basal Medium (BM), supplemented with 20\% Fetal Bovine Serum (FBS; Lonza, Basel, Switzerland), in a humidified incubator at $37^{\circ} \mathrm{C}$ and $5 \% \mathrm{CO}_{2}$. Cells at confluence $>90 \%$ were subcultured by using Tryple Select (Gibco) as a detaching agent.

\section{Myocardial infarction, UCX ${ }^{\circledR}$ delivery, and echocardiography}

Adult C57BL/6 mice (Charles River, Wilmington, MA, USA) aged 8 to 12 weeks, were used for this study, independent of gender. Myocardial infarction was experimentally induced by LAD coronary artery ligation, as previously described [49] with minor alterations. In brief, mice were anesthetized by intraperitoneal injection (ip) of medetomidine $(1 \mathrm{mg} / \mathrm{kg}$, Sededorm; ProdivetZN, Lisboa, Portugal) and ketamine $(75 \mathrm{mg} / \mathrm{kg}$, Clorketam; Vétoquinol, Lure, France), orally intubated, and mechanically ventilated by using a small-animal respirator (Minivent 845; Harvard Apparatus, Holliston, MA, USA). Animals were kept on warming pads throughout the surgical procedure and until full recovery. Under a stereomicroscope (Leica EZ4; Leica Microsystems, Wetzlar, Germany), the heart was exposed ( $\varnothing 5$ to $7 \mathrm{~mm}$ ) via left thoracotomy on the third intercostal space, and the pericardial sac was gently disrupted. The first portion of the LAD coronary artery was visualized below the left atrium, as a pulsating bright red vessel. A nonabsorbable 7.0 suture (Silkam; B. Braun, Melsungen, Germany) was passed under the artery, and the ligation was performed.

After LAD ligation, $2 \times 10^{5} \mathrm{UCX}^{\oplus}$ in $0.5 \%$ Bovine Serum Albumin (BSA; Merck, Whitehouse Station, NJ, USA)/phosphate-buffered saline (PBS; Gibco) were delivered by four intramyocardial injections of $5 \mu \mathrm{l}$ each, with a Hamilton syringe (Hamilton, Reno, NV, USA) attached to a 30-gauge needle $(n=5)$. A group of control animals $(n=10)$ were subjected to the same surgical procedure, although injected only with the vehicle $(0.5 \%$ BSA in PBS). The intercostal incision was closed by an absorbable 6.0 suture (Safil; B. Braun), and surgical staples were used for skin closure. Anesthesia was reversed by $5 \mathrm{mg} / \mathrm{kg}$ ip atipamezole (Revertor; Virbac, Carros, France). Analgesia and fluid therapy were performed by ip delivery of butorphanol (1 mg/kg; Butador; Richter Pharma AG, Wels, Austria) and subcutaneous injection of $5 \%$ glucose physiologic saline (B. Braun), respectively. This procedure was repeated every 12 hours up to 72 hours after surgery or until full recovery.

Transthoracic echocardiography was performed at 7 and 14 days after LAD coronary artery ligation by using a portable ultrasound apparatus (GE Vivid I; General Electric, Fairfield, CT, USA) equipped with a $12-\mathrm{MHz}$ linear probe (GE 12 L-RS Linear Array Transducer; General Electric). Animals were anesthetized (Clorketam, $100 \mathrm{mg} / \mathrm{kg}$ ) and placed on left lateral decubitus position. Two-dimensional (2D) mode images of parasternal short-axis view were acquired to position the Motion-mode (M-mode) cursor at the level of the papillary muscles and perpendicularly to the interventricular septum and left ventricle (LV) free-wall. To evaluate LV structural changes, several parameters from M-mode were measured (that is, the LV internal diameter at diastole (LVIDd) and at systole (LVIDs). Left ventricular ejection fraction (EF) and fraction shortening (FS) were calculated as an index of systolic function: FS (\%) = $(($ LVIDd - LVIDs $) /$ LVIDd $) \times 100$ and EF $(\%)=\left(\left(\right.\right.$ LVIDd $^{3}-$ $\left.\left.\mathrm{LVIDs}^{3}\right) / \mathrm{LVIDd}^{3}\right) \times 100$. The same parameters were measured on control nonmanipulated (np) healthy animals $(n=10)$.

\section{Histologic procedures and immunohistochemistry}

At 14 days after surgery, animals were deeply anesthetized by ip injection of pentobarbital (Eutasil; CEVA, Algés, Portugal, $70 \mathrm{mg} / \mathrm{kg}$ ). After $4 M$ potassium chloride (Sigma-Aldrich, St. Louis, MO, USA) injection, diastole-arrested hearts were harvested, briefly washed in PBS, and fixed in $10 \%$ formalin neutral buffer (Prolabo; VWR International, Radnor, PA, USA) up to 24 hours before paraffin embedding. Representative sampling of the LV (approximately 12 sections, $3 \mu \mathrm{m}$ ) was obtained by transverse sectioning from the apex to the base of paraffin-embedded hearts with an interval of $300 \mu \mathrm{m}$ between each section. Infarct-size assessment was performed by staining paraffin sections with modified Masson trichrome staining (MT), according to the Trichrome (Masson) Stain kit (Sigma-Aldrich), with the following modifications: nuclei were prestained with Celestine Blue solution after staining with Gill's 
Hematoxylin and incubation for 1 hour in aqueous Bouin solution to promote uniform staining.

Immunostaining of heart sections were performed as follows. After antigen recovery, sections were permeabilized with $0.2 \%$ Triton X-100 (Sigma-Aldrich) for 5 minutes and incubated 1 hour in 4\% FBS/1\% BSA in PBS for blocking unspecific staining. For CD31 immunodetection, sections were incubated with primary antibody (sc1506, goat anti-mouse CD31; Santa Cruz Biotechnology, Dallas, TX, USA), diluted 1:400 in the blocking solution, for 2 hours at room temperature (RT). Thereafter, sections were incubated with the secondary antibody (A11057, 568 AlexaFluor donkey anti-goat IgG; Invitrogen) diluted 1:1,000 in blocking solution, for 1 hour at RT. Sections were finally mounted by using Fluoroshield containing DAPI (F6057; Sigma-Aldrich), for nuclei detection.

The extent of apoptosis in the cardiac tissue was assessed by TUNEL assay (ApopTag Fluorescein In Situ Apoptosis Detection Kit; Millipore, Billerica, MA, USA), preceded by antigen recovery with Proteinase K (SigmaAldrich; $20 \mu \mathrm{g} / \mathrm{ml}$, for 15 minutes at $37^{\circ} \mathrm{C}$ ). Images were acquired with the inverted fluorescence microscope Axiovert 200 Motorized and an AxioCam MRm camera (Zeiss, Oberkochen, Germany). Quantification of apoptotic and endothelial cells was performed by using Image 1.42 software (National Institutes of Health (NIH), Bethesda, MD, USA).

\section{Measurement of myocardial infarct size and morphometric analysis}

For infarct-size determination, the collagen deposition highlighted (blue) in MT-stained sections was used to define the LV scarred region. Images of histologic sections were captured with an Olympus SZX10 stereomicroscope and Olympus DP21 camera (Shinjuku, Tokyo, Japan). The percentage of the ischemic LV wall was calculated by using the semiautomated software MIQuant [50] by two different methods: the area measurement [49] and the midline length measurement [51].

Morphometric analysis was performed by resorting to Image J software (NIH). Wall thickness was calculated as the average of the distance across the wall of five equidistant points of the ischemic wall. Lumen-area percentage was calculated by the ratio between the lumen delimited by the endocardium and the total LV area.

\section{Conditioned medium collection and processing}

$\mathrm{UCX}^{\oplus}$ was seeded in BM supplemented with $5 \%$ FBS and grown until $90 \%$ confluence. After washing cells with PBS, BM (without serum) was added, and 24 hours preconditioning under normoxia $\left(37^{\circ} \mathrm{C}, 5 \% \mathrm{CO}_{2}\right)$ or hypoxia $\left(37^{\circ} \mathrm{C}, 5 \% \mathrm{CO}_{2}, 1 \% \mathrm{O}_{2}\right)$ was performed. Thereafter, $\mathrm{BM}$ was replaced and conditioned for 48 hours at $37^{\circ} \mathrm{C}$ and $5 \% \mathrm{CO}_{2}$, after which it was collected, centrifuged at $300 \mathrm{~g}$ for 10 minutes to remove cell debris, filtered $(0.22-\mu \mathrm{m}$ pore size, Millipore), and concentrated in $5-\mathrm{kDa}$ cut-off spin concentrators (Agilent Technologies, Santa Clara, CA, USA). Conditioned medium produced by $\mathrm{UCX}^{\ominus}$ subjected to normoxia $(\mathrm{CMN})$ or hypoxia $(\mathrm{CMH})$ was frozen at $-80^{\circ} \mathrm{C}$ for further use.

\section{Apoptosis assay}

The cardiomyocytic cell line HL-1 was maintained in Claycomb supplemented medium (SAFC Biosciences, Lenexa, KS, USA), according to authors instructions (please refer to [52] for details). HL-1 cells were seeded (50,000 cells $/ \mathrm{cm}^{2}$ ) on $\varnothing 5$-mm coverslips (Thermo Scientific, Waltham, MA, USA) overnight. Immediately before subjecting HL-1 to hypoxia $\left(1 \% \mathrm{O}_{2}\right)$, medium was changed to Claycomb basal medium supplemented with either (a) $\alpha$-MEM basal medium (BM); (b) concentrated CMN, (c) concentrated $\mathrm{CMH}$ (ninefold dilution), or (d) BM $+10 \%$ FBS. After 48 hours of hypoxia $(n=3)$, HL-1 cells were fixed in $1 \%$ paraformaldehyde (PFA; Sigma-Aldrich) in PBS (15 minutes, RT), and the percentage of apoptotic cells was determined by using the ApopTag kit (Millipore) followed by image acquisition by the inverted fluorescence microscope Axiovert 200 (Zeiss).

\section{Vasculogenesis assay}

The vasculogenesis assay was performed as described in [53], by using the thick gel method of preparation. In brief, Matrigel growth factor reduced (BD Biosciences, San Jose, CA, USA) was thawed overnight and poured carefully into eight-well chamber slide LabTeks (Nalgene Nunc, Thermo Scientific; $10^{5} \mu \mathrm{l} /$ well), followed by incubation at $37^{\circ} \mathrm{C}$ for 45 minutes to allow jellification. Afterwards, human umbilical vein endothelial cells (HUVECs; Science Cell 8000; Corte Del Cero, Carlsbad, CA, USA) up to P10 were cultured $\left(45,000 / \mathrm{cm}^{2}\right)$ on top of Matrigel in Endothelial Basal Medium-2 (EBM-2; Lonza) $+1 \%$ $\mathrm{P} / \mathrm{S}$ supplemented (1:9 dilution) with (a) $\alpha$ - MEM basal medium (BM), conditioned medium produced by $\mathrm{UCX}^{\circ}$ subjected to (b) normoxia (CMN) or (c) hypoxia (CMH) preconditioning. After incubation at $37^{\circ} \mathrm{C}$ and $5 \% \mathrm{CO}^{2}$ for 3.5 hours, cells were washed in PBS and stained with Calcein AM (C1430; Invitrogen) Images were acquired by using the inverted fluorescence microscope Axiovert 200 (Zeiss). Tube formation, number of branching points, and tube length and thickness were manually measured by using ImageJ1.42 (NIH), analyzing approximately 25 fields per replicate $(n=3)$.

\section{Isolation and culture of adult murine heart Sca- $1^{+}$cardiac} progenitor cells (CPCs)

Sca- $1^{+}$CPCs were extracted and selected by immunomagnetic cell sorting (MACS; Miltenyi Biotec, Bergisch 
Gladbach, Germany). In brief, hearts from six adult C57BL/6 mice were harvested, dissociated by using the GentleMACS Dissociator (Miltenyi Biotec), and digested with $600 \mathrm{U} / \mathrm{ml}$ Collagenase II (4176; Worthington, Lakewood, NJ, USA) and $60 \mathrm{U} / \mathrm{ml}$ DNAseI (A3778; Applichem Lifesciences, Gatersleben, Germany) for 30 minutes at $37^{\circ} \mathrm{C}$ with agitation (100 rpm). Immunomagnetic cell sorting was performed by incubating the single-cell suspension with Sca-1-FITC antibody (MACS; Miltenyi Biotec) followed by anti-FITC Microbeads (MACS; Miltenyi Biotec). Sca- $1^{+}$CPCs were maintained in $\alpha$-MEM basal medium (BM) supplemented with $10 \%$ FBS. Cells were split at $90 \%$ confluence and used until passage 3 .

Sca- $1^{+}$CPCs metabolic activity, proliferation assessment, and quantitative real-time PCR (qRT-PCR)

Sca- $1^{+}$CPCs were trypsinized and seeded in four different media: (a) $\alpha$-MEM basal medium (BM); (b) basal medium supplemented with 10\% FBS (BM + FBS); (c) CMN; or (d) $\mathrm{CMH}$. After 72 hours of culture, media were replaced by $10 \%$ resazurin (R7017; Sigma-Aldrich) in BM and incubated for 3 hours, after which absorbance at $590 \mathrm{~nm}$ was measured. Metabolic activity values are expressed relative to BM treatment for each initial cell-plating density.

Proliferation was assessed by Ki67 immunostaining in CPCs fixed in 4\% PFA and permeabilized with $0.2 \%$ Triton-X for 2 minutes. After blocking with 4\% FBS/1\% BSA in PBS for 1 hour, cells were incubated with anti-Ki67 primary antibody (1:200, ab15580; Abcam, Cambridge, England) overnight at $4^{\circ} \mathrm{C}$ and subsequently with the secondary antibody Alexa Fluor 568 donkey anti-rabbit (1:300, A-10042; Invitrogen), for 2 hours at RT. Images were acquired by the inverted fluorescence microscope Axiovert 200 (Zeiss), and percentage of $\mathrm{Ki} 67^{+}$cells was manually determined by counting approximately five fields with 30 to 50 cells per field, per replicate and medium condition.

For qRT-PCR, RNA was extracted by using RNAeasy extraction kit (Qiagen, Hilden, Germany) and reverse transcribed by using PrimeScriptRT reagent kit (RR037A; Takara, Tokyo, Japan). PCR was performed by using the iQSYBR Green SuperMIX (BioRad, Hercules, CA, USA) and according to the iQ5 Real-Time PCR Detection System (BioRad). Primer sequences and temperature cycles will be available on request. mRNA expression was defined as primer efficiency to the power of the difference in threshold cycle values between the gene of reference $(G A D P H)$ and the gene of interest. Values were expressed relative to those derived from CPCs cultured in standard conditions $(\mathrm{BM}+10 \% \mathrm{FBS})$.

\section{Data and statistical analysis}

Values presented in text and figures are as mean \pm standard error of the mean of at least three independent experiments. Statistical analysis was performed by using Graph Pad Prism (v5, La Jolla, CA, USA) software, evaluated by unpaired one-way ANOVA test by using Newman-Keuls post hoc test for correction of multiple comparisons, and differences were considered significant when $* P<0.05$, ${ }^{* *} P<0.01$, or ${ }^{* * *} P<0.0001$.

\section{Results}

Intramyocardial transplantation of UCX ${ }^{\circledast}$ preserves cardiac performance and attenuates adverse LV remodeling

\section{2 weeks after MI}

$\mathrm{UCX}^{\oplus}$ were isolated by using a proprietary method (PCT/IB2008/054067) that yields a well-defined number of cells by using a precise proportion between tissuedigestion enzyme activity units, tissue mass, digestion solution volume, and void volume. These cells displayed plastic adherence, fibroblast-like morphology, and an antigenic profile typical of mesenchymal stromal cells [13] (see Additional file 1: Figure S1), as defined by the International Society for Cellular Therapy [54].

To evaluate the therapeutic potential of the $\mathrm{UCX}^{\odot}$ in an MI setting, cells were delivered via intramyocardial injection to mice subjected to permanent ligation of the LAD coronary artery. Infarcted animals that received only the vehicle were used as control. Transthoracic echocardiography performed at 1 and 2 weeks after MI revealed consistent $L V$-chamber dilation and impaired LV function in all MI groups (Figure $1 \mathrm{~A}$ through D). Although no beneficial effect of $\mathrm{UCX}^{\oplus}$ delivery could be recognized at 1 week after $\mathrm{MI}$, a tendency to decreased EF and FS in transplanted hearts was evident (Figure 1C, D). Conversely, at 2 weeks after MI, a significantly reduced diastolic LV-chamber dilation could be verified in cell-transplanted mice when compared with the vehicle control group (Figure 1A, B). Moreover, although not reaching statistical significance, EF and FS had inverted the tendency observed at 1 week and were augmented in the cell-transplanted group when compared with vehicle-injected hearts (Figure 1C, D). Overall, UCX ${ }^{\odot}$ transplanted hearts preserved systolic function 2 weeks after surgery, contrarily to the progressive loss of cardiac function observed in the vehicle group.

Widespread cell death and degradation of the cardiac extracellular matrix in the ischemic myocardium culminates in a substantial thinning of the LV wall, LV chamber dilation, and formation of a collagenous-rich nonfunctional scar; alterations that are commonly designated as cardiac remodeling. Stereoscopic view of representative cross-sections of infarcted hearts harvested at 2 weeks after surgery showed that LV free-wall thinning and LV chamber dilation occurred in both experimental groups (Figure 1E). Morphometric analysis of the LV crosssections revealed that $\mathrm{UCX}^{\oplus}$ transplanted hearts exhibited a less-pronounced decrease (by $41.1 \% \pm 13.8 \%$ ) in 


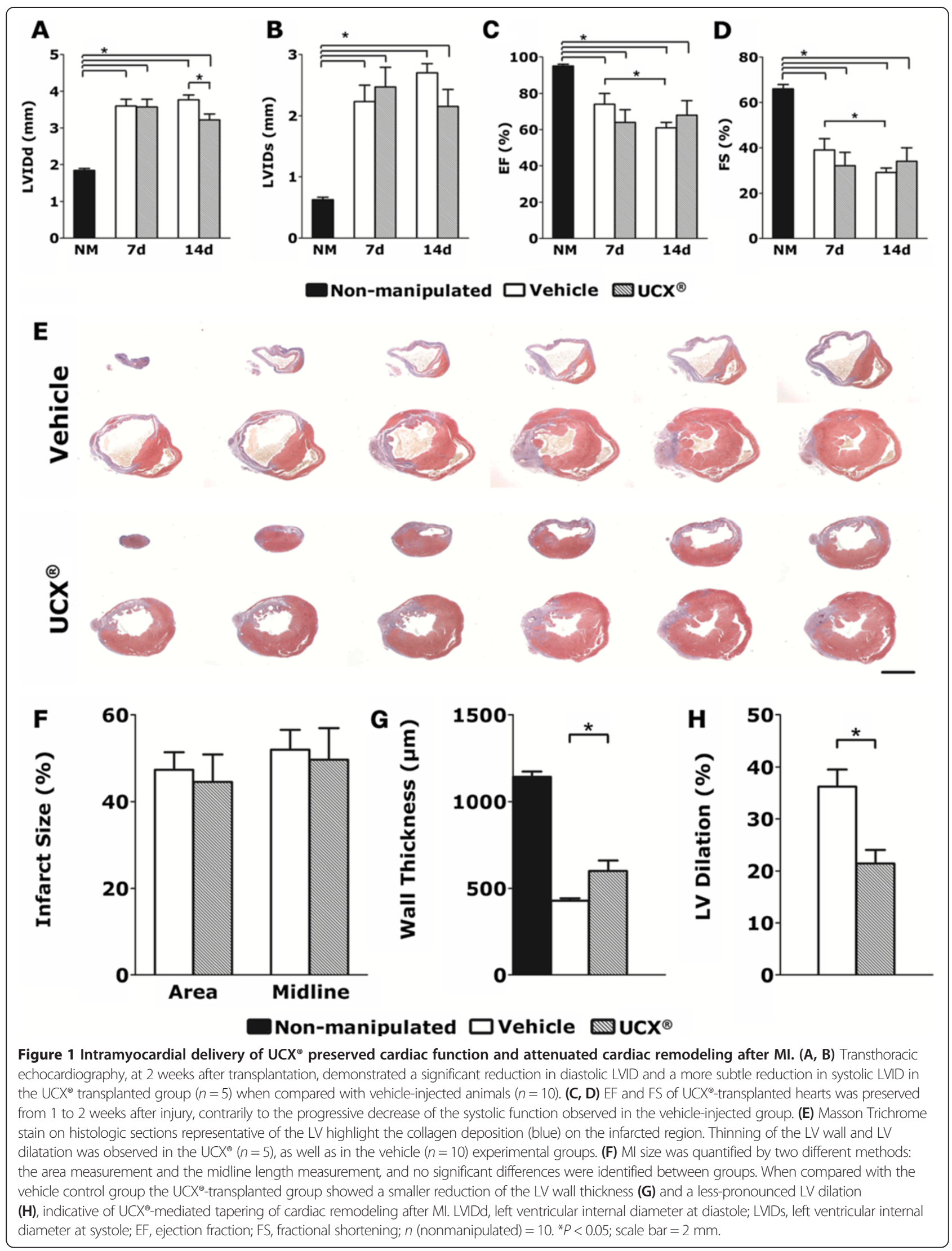


thickness of infarcted LV wall (Figure 1G) than the vehicle control group. Moreover, the $\mathrm{UCX}^{\oplus}$-injected group displayed a $40.8 \% \pm 7.2 \%$ reduction in the endocardial diameter, relative to the vehicle-control (Figure $1 \mathrm{H}$ ), similar to what was observed in the echocardiographic assessment of the LVIDd (Figure 1A). These data suggest an UCX mediated cardiac protective effect through attenuation of the infarct expansion and LV remodeling after MI.

Despite these evidences, no differences in infarct size (calculated on the basis of collagen deposition) were observed between vehicle and $\mathrm{UCX}^{\odot}$ transplanted MI animals (Figure 1F).

UCX ${ }^{\circledR}$ cells stimulate angiogenesis and prevent apoptosis in the infarcted myocardium

To evaluate whether the cardiac improvement observed after MI could be in part a result of improved neovascularization, CD31-expressing cells $\left(\mathrm{CD} 31^{+}\right)$were immunolabeled and counted in the infarcted and peri-infarcted regions of all experimental groups. Quantification of $\mathrm{CD} 1^{+}$cells demonstrated a clear increase in the number of endothelial cells of the microvasculature on UCXtransplanted hearts (Figure 2B) over the vehicle group (Figure 2A). This increase was more pronounced in the myocardium adjacent to the ligation region $(32.9 \% \pm 7.8 \%)$ than in the apex region $(25.3 \% \pm 11.8 \%)$ of the $\mathrm{LV}$ (Figure 2C).

Moreover, the anti-apoptotic potential of $\mathrm{UCX}^{\oplus}$ was evaluated on the infarcted and peri-infarcted regions (Figure 2D and E). The number of apoptotic cells in the apex of $\mathrm{UCX}^{-}$-transplanted hearts was reduced by $39.0 \%$ $\pm 8.7 \%$ when compared with the same region of vehicleinjected hearts (Figure 2F).

Although a beneficial effect of $\mathrm{UCX}^{\oplus}$ in cardiac repair following MI could be established, it remained to be elucidated whether functional and histologic improvement was a direct result of $\mathrm{UCX}^{\odot}$ engraftment in the injured hearts. To assess this, paraffin-embedded heart tissue sections were stained with a monoclonal antibody directed against the nuclei of human cells. Nuclear-specific staining could not be found (see Additional file 1: Figure S2), indicating that $\mathrm{UCX}^{\oplus}$ did not engraft the murine heart in this experimental setting. Human muscle tissue subjected to similar processing was used as positive control.

\section{$\mathrm{UCX}^{\circledR}$ enhances cellular vasculogenesis in vitro via a} paracrine mechanism

Given that $\mathrm{UCX}^{\oplus}$ did not engraft murine hearts, we postulated that the observed cardioprotective effects could have been exerted primarily through paracrine mechanisms.
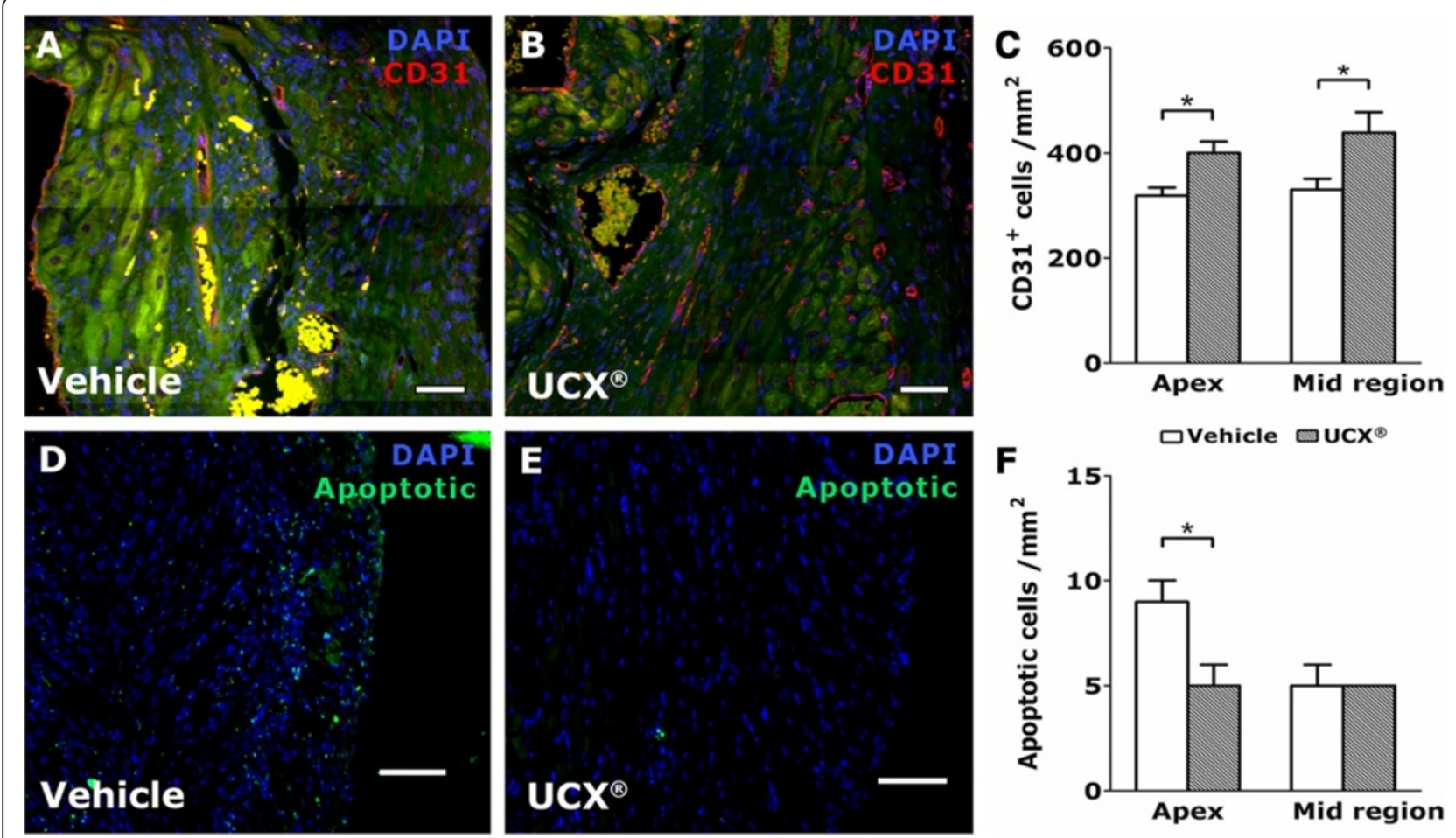

Figure 2 Transplantation of UCX ${ }^{\circledast}$ into MI hearts increased capillary density and decreased apoptosis. Representative images of vehicleinjected ( $n=6, \mathbf{A}$ and $\mathbf{D}$ ) and $U X^{-}$-transplanted hearts ( $n=5, \mathbf{B}$ and $\left.\mathbf{E}\right)$ stained for CD31 (A and $\mathbf{B}$, red) and for cellular apoptosis (D and $\mathbf{E}$, bright green). (C) CD31-expressing cells were more abundant within the infarcted LV wall of UCX ${ }^{\circledR}$-transplanted hearts when compared with the vehicle control group. (F) UCX ${ }^{\oplus}$-transplanted hearts showed fewer apoptotic cells in the apical region when compared with vehicle-injected hearts, suggesting an anti-apoptotic protective effect by the UCX ${ }^{\otimes}$. Green filter in $\mathbf{A}$ and $\mathbf{B}$ denotes tissue autofluorescence. ${ }^{*} P<0.05$; scale bars $=100 \mu \mathrm{m}$. 
Thus, conditioned medium produced by $\mathrm{UCX}^{\oplus}$ subjected to either normoxia $(\mathrm{CMN})$ or hypoxia $(\mathrm{CMH})$ preconditioning was collected for further investigation. Because $\mathrm{UCX}^{\oplus}$ enhanced the number of cells expressing the prototypical endothelial marker CD31 in MI-hearts in vivo, we addressed whether the $\mathrm{UCX}^{\ominus}$-conditioned media were able to enhance the formation of capillary-like structures by endothelial cells (HUVECs) in vitro, by using a classic vasculogenesis assay (Matrigel). In comparison with HUVECs seeded in endothelial basal medium (EBM-2) supplemented with BM (Figure 3A), cells cultured in CMN (Figure $3 \mathrm{~B}$ ) or $\mathrm{CMH}$-supplemented media (Figure $3 \mathrm{C}$ ) showed an increased number of capillary-like structures (by $42.7 \% \pm 5.6 \%$ in $\mathrm{CMN}$ and $53.1 \% \pm 4.7 \%$ in $\mathrm{CMH}$, Figure 3D), as well as branching points (by $35.8 \% \pm 5.6 \%$ in $\mathrm{CMN}$ and $47.4 \% \pm 4.3 \%$ in $\mathrm{CMH}$, Figure $3 \mathrm{E})$. The caliber of the tubes formed was also affected, as HUVECs cultured in CMN- or CMH-supplemented EBM-2 displayed lengthier (by $35.8 \% \pm 3.2 \%$ in $\mathrm{CMN}$ and $55.5 \% \pm 3.7 \%$ in $\mathrm{CMH}$, Figure $3 \mathrm{~F}$ ) and thicker (by $81.4 \% \pm 6.8 \%$ in $\mathrm{CMN}$ and $94.8 \% \pm 8.8 \%$ in $\mathrm{CMH}$, Figure $3 \mathrm{G}$ ) capillary-like structures, when compared with BM-supplemented medium. These results strongly support that $\mathrm{UCX}^{\odot}$ favors angiogenic processes by a paracrine mechanism, thus corroborating the aforementioned in vivo observations (Figure $2 \mathrm{~A}$ through $\mathrm{C}$ ).

\section{UCX ${ }^{\circledast}$ display a paracrine protective effect against the} apoptotic damage of $\mathrm{HL}-1$ cardiomyocytes in vitro The UCX ${ }^{\oplus}$-mediated apoptotic protective effect detected in transplanted MI hearts (Figure 2D through F) led us to investigate whether $\mathrm{UCX}^{\oplus}$-conditioned medium recapitulated such effects in vitro.
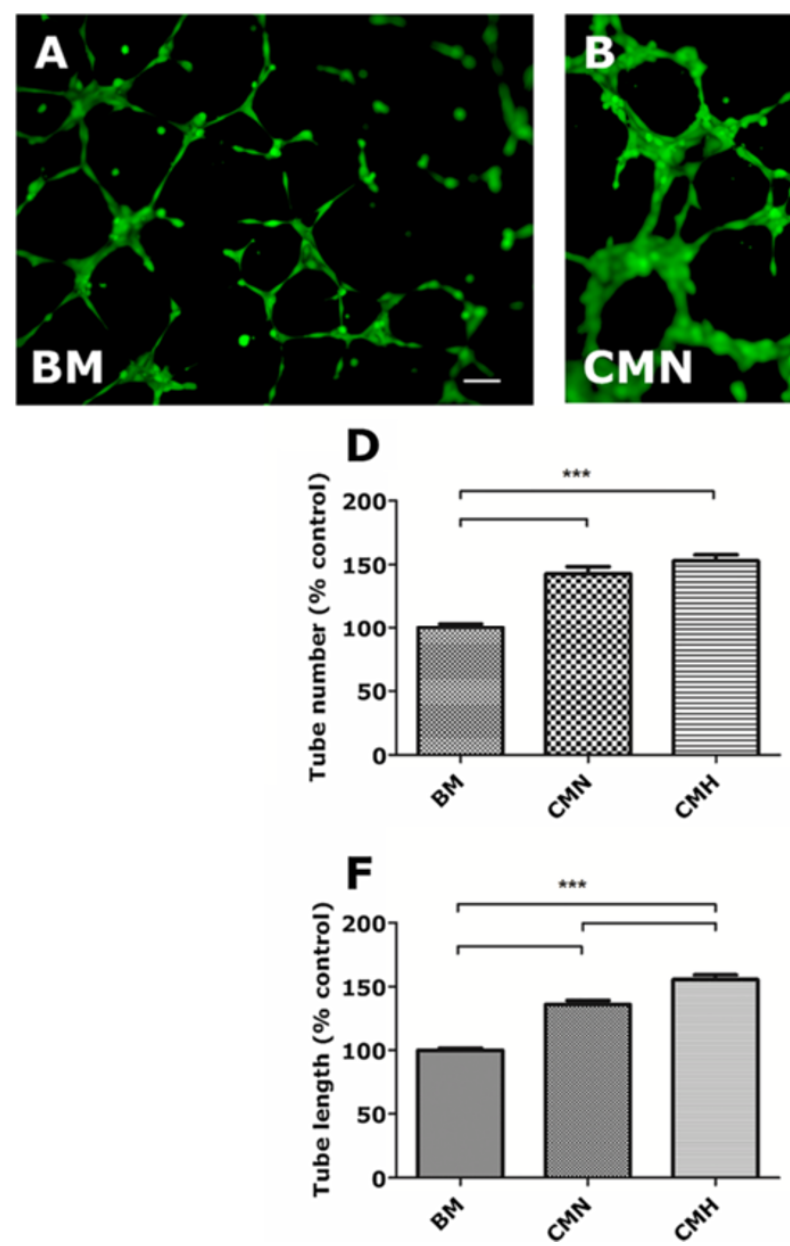
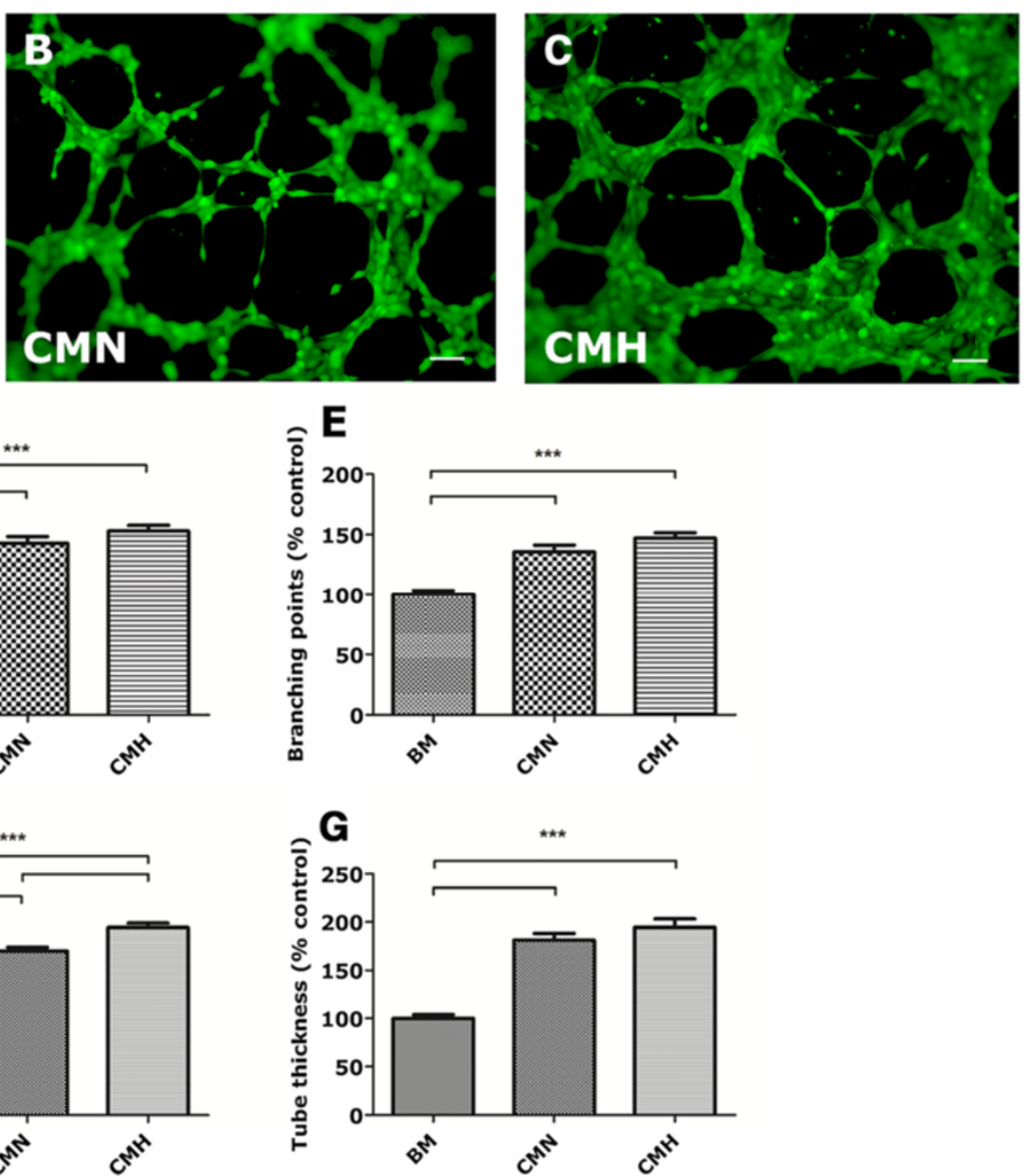

Figure 3 Paracrine effect of UCX ${ }^{\otimes}$ in in vitro vasculogenesis by HUVECs. Matrigel assay was performed by seeding HUVECs in EBM-2 supplemented with BM (A), CMN (B) or CMH (C) for 3,5 hours. Cells seeded in UCX ${ }^{\oplus}$-conditioned media formed more capillary-like structures ( $\mathbf{D}$, by $42.7 \% \pm 5.6 \%$ in $\mathrm{CMN}$ and $53.1 \% \pm 4.7 \%$ in $\mathrm{CMH}$ ) and branching points (E, by $35.8 \% \pm 5.6 \%$ in $\mathrm{CMN}$ and $47.4 \% \pm 4.3 \%$ in $\mathbf{C M H}$ ), suggesting a pro-angiogenic effect. The tubes formed in CMN- or CMH-supplemented media were longer (F, by $35.8 \% \pm 3.2 \%$ in $\mathrm{CMN}$ and $55.5 \% \pm 3.7 \%$ in $\mathrm{CMH}$ ) and thicker (G, by $81.4 \% \pm 6.8 \%$ in $\mathrm{CMN}$ and $94.8 \% \pm 8.8 \%$ in $\mathrm{CMH}$ ), in comparison to those formed in $\mathrm{BM}$, further corroborating the observed in vivo vasculogenic effect. ${ }^{* *} P<0.0001$. 
For this purpose, the HL-1 cell line, a gold-standard system for investigating cardiomyocytes in vitro, was used. These cells are able to maintain a differentiated cardiac phenotype while beating in culture.

HL-1 cells subjected to hypoxic conditions for 48 hours increased the apoptotic rate by approximately 2.4-fold in serum-supplemented medium and to 3.6-fold in serumfree medium (Figure 4A through $\mathrm{C}$ ). $\mathrm{UCX}^{\oplus}-\mathrm{CMN}$ and $\mathrm{CMH}$ significantly halved the number of TUNEL-positive cells when compared with BM (Figure 4D through F). No significant differences were found in the protection against the hypoxia-induced HL-1 apoptotic damaged between $\mathrm{CMN}$ and $\mathrm{CMH}$.

UCX $^{\circledR}$-derived conditioned media stimulate resident CPCs proliferation and activate a cardiomyogenic gene-expression program

Whereas the reportedly low proliferation of mature cardiomyocytes [55] makes it an unlikely event to be accomplished in the time frame of our experimental in vivo setting, a stimulation and/or activation of the myocardium undifferentiated cells cannot be disregarded. Therefore, to further dissect the mechanisms involved in $\mathrm{UCX}^{\oplus}$-mediated beneficial effects in MI, we addressed whether resident CPCs could be responsive to $\mathrm{UCX}^{\oplus}$ conditioning. Sca- $1^{+}$
CPCs were maintained in either BM, BM-supplemented with FBS, UCX $-\mathrm{CMN}$, and $\mathrm{UCX}-\mathrm{CMH}$ for 72 hours. Although the treatment with both $\mathrm{UCX}^{\oplus}$-conditioned media favored CPCs metabolic activity (Figure 5A) relative to basal culture medium, a differential effect was observed between CMN and CMH concerning CPCs proliferation and commitment. Hence, although both $\mathrm{CMN}$ and $\mathrm{CMH}$ enhanced the proliferation of Sca- $1^{+}$CPCs, this effect was more pronounced in response to CMN (Figure 5B). Moreover, higher expression levels of early (Gata4, Nkx2.5) and late ( $\alpha$ heavy chain subunit of cardiac myosin, Myh6) cardiac markers revealed that the UCX ${ }^{-} \mathrm{CMH}$ triggers Sca- $1^{+}$ CPCs cardiomyogenic commitment, when compared with the other experimental groups (Figure 5C through $\mathrm{G}$ ). CMN also induced the expression by CPCs of Gata-4 and Myh6, however, not attaining the levels observed with $\mathrm{CMH}$. Importantly, the results displayed in Figure 5 were verified for three independent experiments (each performed in duplicate) with different batches of conditioned media as well as different preparations of primary cells.

\section{Discussion}

Previous studies have demonstrated that BM-MSCs transplantation has the potential to improve cardiac function and LV remodeling after infarction [56-60]. However, in

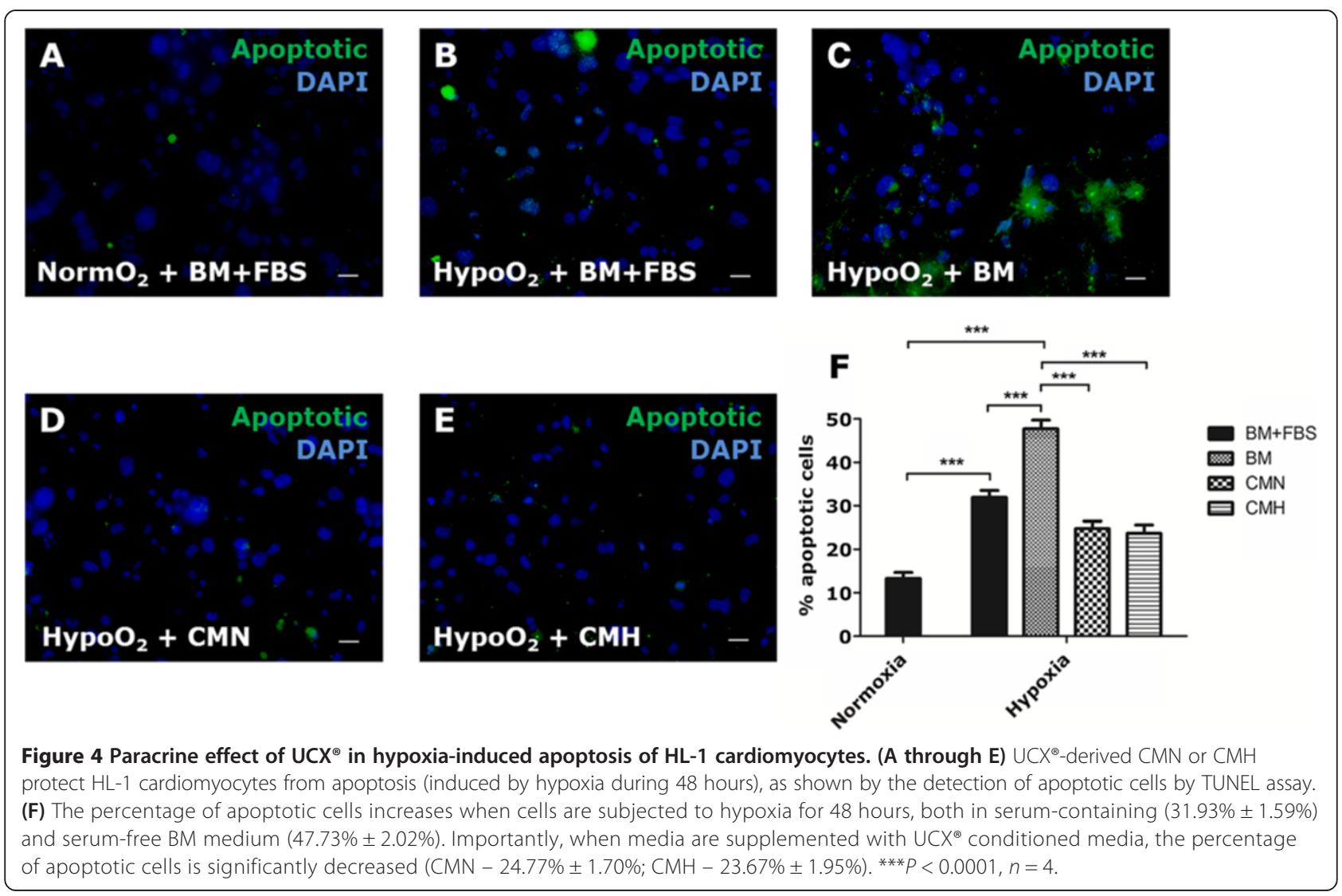




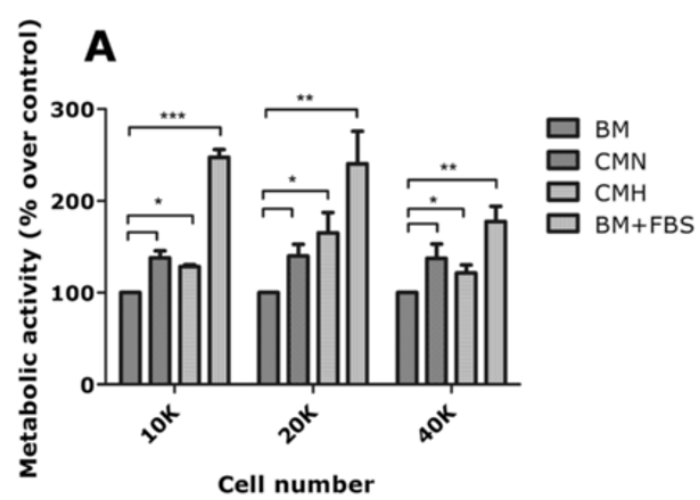

\section{B}
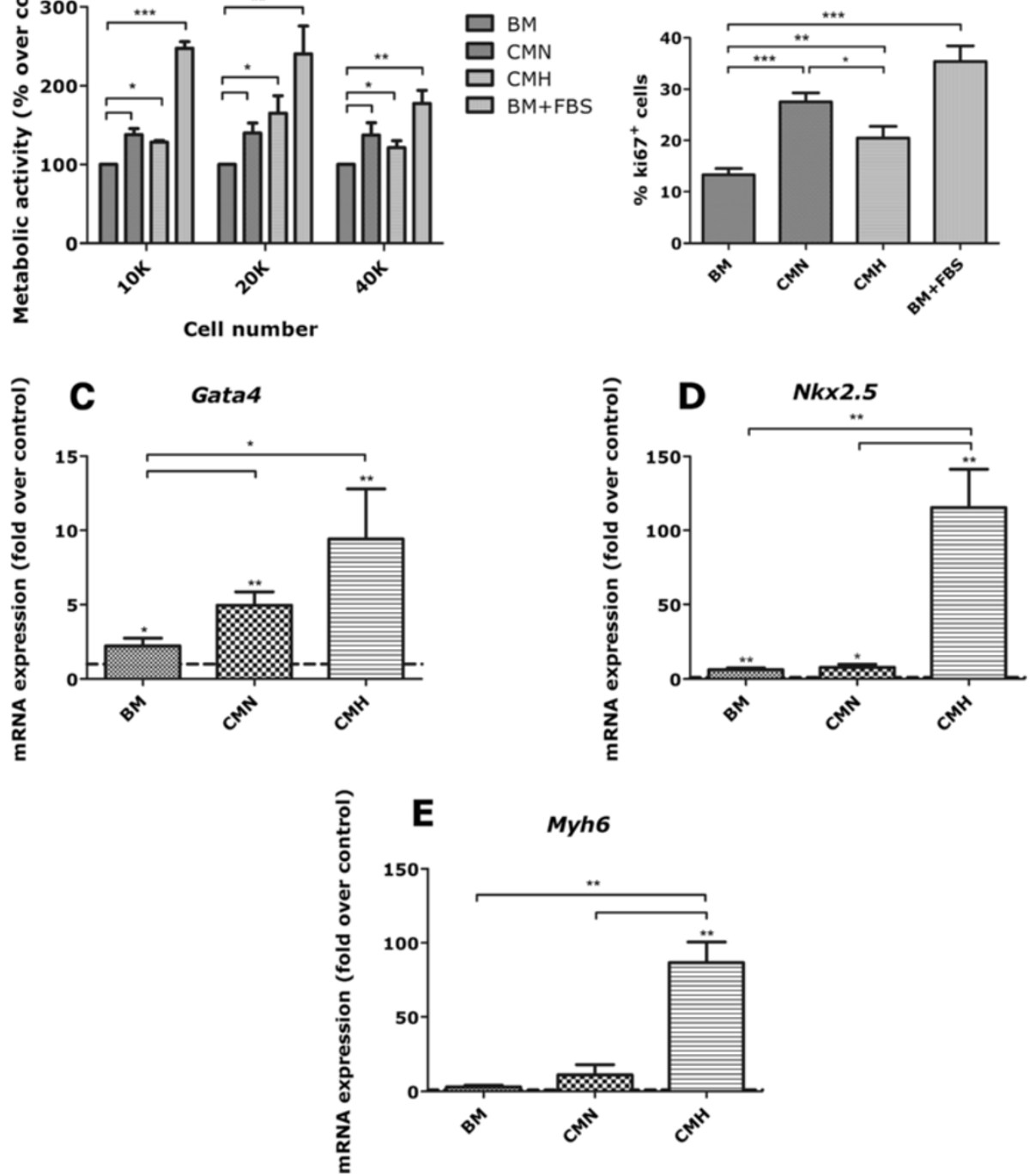

Figure 5 Paracrine effect of UCX ${ }^{\circledR}$ on CPCs proliferation and cardiac commitment. Treatment of SCa- $1^{+}$CPCS with UCX ${ }^{\oplus}$-derived conditioned media for 72 hours results in enhanced metabolic activity (A) and cellular proliferation (B), when compared with the treatment with basal medium ( $n=4 ;{ }^{*} P<0.05$; ${ }^{*} P<0.01$; $\left.{ }^{* *} P<0.0001\right)$. (C through E) Treatment with $\mathrm{UCX}{ }^{\oplus}$-derived $C M H$ and, to a lesser extent, $C M N$ triggers $C P C S$ cardiac commitment, as shown by higher expression of early (Gata4, Nkx2.5) and late (Myh6) cardiac-affiliated markers in comparison with basal-medium treated CPCs ( $n=3$; values were normalized to those of standard culture conditions: BM $+10 \%$ FBS, represented by the dotted lines in each graph. ${ }^{*} P<0.05 ;{ }^{*} P<0.01$, either between groups indicated in brackets, or between $\mathrm{BM}+10 \% \mathrm{FBS}$ and the group represented by the asterisk placed above its corresponding column).

clinical terms, the use of BM-MSCs presents some severe limitations: (a) the procurement process requires an invasive surgical procedure, (b) the BM-MSCs frequency in the native tissue is very low $(1: 10,000$ total cells in bone marrow), resulting in heterogeneous BM-MSCs preparations that are difficult to replicate; (c) the efficiency of BM-MSCs isolation is also highly dependent on the patient's clinical history and on the adopted isolation process, and finally, (d) BM-MSCs isolation, in a clinical setting, involves complex logistics and specialized clinicians, which very seldom occur concomitant with common hospital environments $[12,61]$. In the present work, MSCs isolated from the umbilical cord Wharton's jelly using technology developed by us, and designated UCX ${ }^{\oplus}$, come forth as an allogeneic, off-the-shelf cell-product that can be further regarded as the active substance for advanced therapeutic options towards restoration of the injured myocardium. In this $\mathrm{MI}$ murine model, $\mathrm{UCX}^{\circ}$ transplantation preserves cardiac function after MI through paracrine mechanism(s) that involve the attenuation of the LV 
remodeling process and anti-apoptotic as well as proangiogenic effects. Potential mechanisms involved in the $\mathrm{UCX}^{\oplus}$-mediated cardiac protection were further dissected in vitro by the use of $\mathrm{UCX}^{\circledR}$ conditioned media. $\mathrm{UCX}^{\oplus}$ paracrine effects involve the (a) protection of cardiomyocytes from hypoxia-induced apoptosis, (b) increase in forma-tion of capillary-like structures by endothelial cells, and (c) promotion of resident $\mathrm{Sca}-1^{+}$CPCs proliferation and cardiac commitment.

Although a clear definition of the mechanisms involved in the use of MSCs as therapeutic agents for MI is not available at this point, a panoply of MSCsmediated beneficial effects on cardiac function have been reported (apoptosis, scar formation, and angiogenesis) by using different cell sources (for example, bone marrow, adipose tissue) and animal models (for example, rat, pig). In this work, we showed that $\mathrm{UCX}^{\oplus}$ transplantation precludes a worsened prognosis of MI over time, contributing to the preservation of cardiac function (\% EF and \% FS). Moreover, histologic beneficial outcomes were shown on $\mathrm{UCX}^{\oplus}$ transplantation, such as an increase in LV wall thickness and lower LV dilation, as reported by others $[21,24,25]$. Likewise, our data corroborates that a benefic effect of MSCs occurs through the enhancement of angiogenesis [33] and inhibition of apoptosis [62].

Furthermore, a novel aspect in this work is the indication of alternative mechanisms that could account for the cardioprotective activity of $\mathrm{UCX}^{\oplus}$ (that is, identification of a potential to activate the cardiac commitment/ differentiation and/or augment the frequency of undifferentiated Sca- $1^{+}$CPCs). In this regard, hypoxia preconditioning of $\mathrm{UCX}^{\odot}$ may play an important role in the determination of cell-fate choice and thereby the function of CPCs. Although both $\mathrm{UCX}^{\oplus}$-conditioned media preparations enhanced CPCs metabolic activity, distinct actions were also evident. Thus, $\mathrm{CMN}$ displayed higher mitogenic activity, whereas $\mathrm{CMH}$ had a more pronounced effect in the activation of Sca- $1^{+}$CPCs cardiac commitment, as shown by the higher levels of $N k x 2.5$, Gata4. and Myh6 expression observed in this condition. To the best of our knowledge, this is the first report on the paracrine effects of MSCs in the pool of adult resident undifferentiated cells. Moreover, BM-MSCs have already been shown to affect the differentiation of progenitors isolated from the neonatal heart [63]. Hence, it will be of importance to establish whether the MSCsmediated effects on CPCs observed in vitro correlate with the benefits shown after MSCs transplantation in the onset of MI.

Our study expands the knowledge on the yet-unexplored potential of MSCs derived from umbilical cord tissue to repair the injured heart. Although much work has focused on the properties of MSCs of several distinct sources, only one other study has addressed the umbilical cord tissuederived cells [23]. The latter reports on transplantation of MSCs in a rabbit MI model as leading to a modest functional recovery of the LV in chronic conditions (30 days after MI), but not in the acute phase (5 days after MI). The cardioprotective effect was attributed to moderate engraftment of the xenotransplanted cells, which expressed immature cardiac markers, despite not being able to differentiate fully into functional cardiomyocytes.

Thus, while corroborating such data, we report on the benefits of UCM-MSCs transplantation in cardiac function after MI in a murine model, and provide additional mechanistic insight into the cardioprotective effects observed.

The UCX ${ }^{\oplus}$ were not found to engraft the murine heart in our setting. Nonetheless, despite the high immunologic barrier to xenotransplantation, adding to the hostile inflammatory milieu triggered by $\mathrm{MI}$, and the low dose of administered cells (that is, $2 \times 10^{5}$ cells/heart), the $\mathrm{UCX}^{\oplus}$ exerted a beneficial effect in murine infarcted hearts. Although not addressed in the current study, the $\mathrm{UCX}^{\odot}$ likely interfered with the initial events of acute inflammation characteristic of MI, therefore attenuating LV-remodeling processes, while also favoring angiogenic and cardioprotective effects.

Due the well-acknowledged immunomodulatory nature of MSCs, and in particular, that of the MSCs isolated from the umbilical cord tissue [13], persistence of cells in a human allogeneic transplantation may be conceivably higher, thereby enhancing the cardioprotective effects mediated by the paracrine action herein described. This must be considered when designing new cell therapies (that is, cells could be either transplanted to assure prolonged release of factors [64], or alternatively, could be used for producing factors for subsequent administration to the patient.

Administration of $\mathrm{UCX}^{\oplus}$-conditioned medium into the MI border zone may clarify whether paracrine factors solely are responsible for the effects after $\mathrm{UCX}^{\oplus}$-transplantation. Noteworthy, conditioning by the host tissue of the $\mathrm{UCX}^{\odot}$ after transplantation should not be neglected, as it may lead to the production of paracrine factors that are unlikely replicated by the infusion of conditioned media derived from in vitro cultured cells. Future work will be conducted to elucidate this particular aspect.

Aiming at a clear indication of which factors could account for the $\mathrm{UCX}^{\oplus}$ mediated beneficial effects, the gene-expression pattern of $\mathrm{UCX}^{\oplus}$ was assessed with Affimetrix gene array [GEO:GSE51869] by using cells derived from three different umbilical cords (see Additional file 1: Figure S3). When comparing the expression of those genes with that of positive (CD105, CD73, CD90, and CD44) and negative (CD14, CD19, CD34, CD45, CD31, and HLA-DR) markers of $\mathrm{UCX}^{\oplus}$, it is concluded that the expression of angiogenesis-associated transcripts 
(subtypes of VEGF, angiopoietins, HGF, C-mET, bFGF, TGF- $\beta$, and PDGF-AB) is high. Therefore, several factors are most likely contributing for the cardioprotective effects observed in vivo and in vitro. More-directed work is already under way specifically to identify the role of each of the candidates. Nevertheless, the specific function of these factors in cardiomyocytes protection, vasculogenesis, and $\mathrm{CPC}$ induction must be further investigated for clarification of each of these three mechanisms separately.

Yet another approach to enhance cellular paracrine action is to engineer cells to promote their cardioprotective activity. This has been clearly demonstrated in the work by Mangi and colleagues [65]. By genetically engineering rat BM-MSCs to overexpress the prosurvival Akt-1 gene, a dramatic contribution for the restoration of cardiac function (evaluated ex vivo), and prevention of adverse tissue remodeling, was obtained by intramyocardial transplantation after MI.

Noteworthy, the method of UCX ${ }^{\bullet}$ extraction and subsequent processing has been recently adapted to advanced therapy medicinal product (ATMP) standards, as defined by the guideline on the minimum-quality data for certification of ATMP (EMA/CAT/486831/2008/corr, 2010). Given that our effects $\mathrm{UCX}^{\circ}$ exert in the context of MI, a future clinical usage of this off-the-shelf cellular product can be envisaged.

\section{Conclusions}

Human mesenchymal stromal cells derived from the umbilical cord matrix $\left(\mathrm{UCX}^{\circ}\right)$ preserve cardiac function and attenuate adverse tissue remodeling after intramyocardial transplantation in a murine MI model. The cardioprotective effect of $\mathrm{UCX}^{\circ}$ is exerted through paracrine mechanism(s) that appear to (a) enhance angiogenesis, (b) limit the extent of the apoptosis in the heart, and (c) to increase proliferation and activate the cardiomyogenic gene-expression program in a pool of myocardial resident cardiac progenitor cells.

\section{Additional file}

Additional file 1: The supplementary material includes three additional Figures (Figure S1, Figure S2, and Figure S3) with additional results. The file also includes the respective legend captions and methods.

\footnotetext{
Abbreviations

BM: basal medium; BM + FBS: basal medium supplemented with 10\% fetal bovine serum; BM-MSCs: bone marrow-derived MSCs; BSA: bovine serum albumin; $\mathrm{CMH}$ : conditioned medium produced after hypoxia preconditioning; CMN: conditioned medium produced after normoxia preconditioning; CPCs: cardiac stem/progenitor cells; EF: ejection fraction; FS: fractional shortening; LAD: left anterior descending; LV: left ventricle; LVIDd: left ventricle internal diameter at diastole; LVIDs: left ventricle internal diameter at systole; MI: myocardial infarction; MSC: mesenchymal stromal cell; MT: Masson trichrome; PBS: phosphate-buffered saline; RT: room temperature; UCM-MSC: umbilical cord matrix-derived MSC.
}

\section{Competing interests}

The INEB authors have no conflicts of interest to disclose. PC and $\mathrm{HC}$ are shareholders and JPM, RNB, JA, MF, MT, and JMS are currently employed at ECBio S.A., a company currently developing cellular therapeutics based on human mesenchymal stromal cells.

\section{Authors' contributions}

DSN carried out the in vivo experiments, participated in the conception of the study, was involved in the experimental conception and design, data analysis and interpretation, and manuscript writing; DM performed in vitro experiments with conditioned media, was involved in the experimental conception and design, data analysis and interpretation, and manuscript writing; LMS quantified apoptosis and neovascularization on tissue sections, participated on data analysis and interpretation; MT was involved in the isolation and characterization of UCX as well as in data analysis and interpretation; MF was involved in the isolation and characterization of UCX ${ }^{\circledR}$ as well as in data analysis and interpretation; MV participated in the animal surgeries and organ collection and was involved in data analysis and interpretation; TPR performed and analyzed the Matrigel assay, and was involved in the critical revising of the manuscript; AFA participated in the immunohistologic characterization and analysis of tissue sections; JA participated in the experimental conception and design and in the critical revising of the manuscript. JPM was involved in the generation and characterization of UCX ${ }^{\bullet}$ and data interpretation and analysis; JMS was involved in the conception of the study, experimental conception and design, and in the critical revising of the manuscript; RNB was involved in the conception of the study, experimental conception and design, and in the critical revising of the manuscript; PC was involved in the conception of the study, experimental conception and design, and in the critical revising of the manuscript. HC was involved in the conception of the study, experimental conception and design, and in the critical revising of the manuscript; PP-O was involved in the conception of the study, coordinated and designed the experimental work, and participated in the manuscript writing. All authors read and approved the final manuscript.

\section{Acknowledgements}

This work was supported by ECBio, QREN-LISBOA-01-0202-FEDER-005294, Fundação para a Ciência e a Tecnologia [SFRH/BPD/42254/2007 and NORTE07-0124-FEDER-000005 to D.S.N., SFRH/BD/74218/2010 to M.V., SFRH/BPD/ 80588/2011 to T.P.R., Ciência2007 to P.P.O]; and Fundo Europeu de Desenvolvimento Regional, Programa Operacional Factores de CompetitividadeCOMPETE, Quadro de Referência Estratégico Nacional, Fundo Social Europeu [PEst-C/SAU/LA0002/2011 and PTDC/SAU-ORG/118297/2010]. The funding bodies other than ECBio had no role in design, in the collection, analysis, and interpretation of data; in the writing of the manuscript; or in the decision to submit the manuscript for publication.

The authors thank Prof. William Claycomb for the kind offer of the HL-1 cell-line, and Dr. Werner Lindenmaier, Dr. Kurt Dittmar, and Susanne Pohl for performing the microarray studies.

\section{Author details}

'INEB, Instituto de Engenharia Biomédica, Universidade of Porto, Rua do Campo Alegre, 823, 4150-180 Porto, Portugal. ${ }^{2}$ ICBAS, Instituto de Ciências Biomédicas Abel Salazar, Universidade of Porto, Porto, Portugal. " ${ }^{3}$ ECBio, Investigação e Desenvolvimento em Biotecnologia, S.A, Rua Henrique Paiva Couceiro, 27, 2700-451 Amadora, Portugal. ${ }^{4} \mathrm{CICS}$, Centro de Investigação em Ciências da Saúde, Departamento de Ciências Farmacêuticas, Instituto Superior de Ciências da Saúde, Norte, Paredes, Portugal.

Received: 20 September 2013 Revised: 1 November 2013 Accepted: 20 December 2013 Published: 10 January 2014

\section{References}

1. Roger VL, Go AS, Lloyd-Jones DM, Adams RJ, Berry JD, Brown TM, Carnethon MR, Dai S, de Simone G, Ford ES, Fox CS, Fullerton HJ, Gillespie C, Greenlund KJ, Hailpern SM, Heit JA, Ho PM, Howard VJ, Kissela BM, Kittner SJ, Lackland DT, Lichtman JH, Lisabeth LD, Makuc DM, Marcus GM, Marelli A, Matchar DB, McDermott MM, Meigs JB, Moy CS: Heart disease and stroke statistics, 
2011 update: a report from the American Heart Association. Circulation 2011, 123:e18-e209.

2. Hertz MI, Aurora P, Christie JD, Dobbels F, Edwards LB, Kirk R, Kucheryavaya AY, Rahmel AO, Rowe AW, Stehlik J: Scientific Registry of the International Society for Heart and Lung Transplantation: Introduction to the 2010 annual reports. J Heart Lung Transplant 2010, 29:1083-1088.

3. Segers VF, Lee RT: Stem-cell therapy for cardiac disease. Nature 2008 , 451:937-942.

4. Abdelwahid E, Siminiak T, Guarita-Souza LC, de Carvalho KAT, Gallo P, Shim W, Condorelli G: Stem cell therapy in heart diseases: a review of selected new perspectives, practical considerations and clinical applications. Curr Cardiol Rev 2011, 7:201-212.

5. Le Blanc K, Tammik C, Rosendahl K, Zetterberg E, Ringdén O: HLA expression and immunologic properties of differentiated and undifferentiated mesenchymal stem cells. Exp Hematol 2003, 31:890-896.

6. Owen M, Friedenstein AJ: Stromal stem cells: marrow-derived osteogenic precursors. Ciba Found Symp 1988, 136:42-60.

7. Wexler SA, Donaldson C, Denning-Kendall P, Rice C, Bradley B, Hows JM: Adult bone marrow is a rich source of human mesenchymal 'stem' cells but umbilical cord and mobilized adult blood are not. $\mathrm{Br} J$ Haematol 2003, 121:368-374

8. Yang XF, He X, He J, Zhang LH, Su XJ, Dong ZY, Xu YJ, Li Y, Li YL: High efficient isolation and systematic identification of human adipose-derived mesenchymal stem cells. J Biomed Sci 2011, 18:59

9. Sarugaser R, Lickorish D, Baksh D, Hosseini MM, Davies JE: Human umbilical cord perivascular (HUCPV) cells: a source of mesenchymal progenitors. Stem Cells 2005, 23:220-229.

10. Tsagias N, Koliakos I, Karagiannis V, Eleftheriadou M, Koliakos GG: Isolation of mesenchymal stem cells using the total length of umbilical cord for transplantation purposes. Transfus Med 2011, 21:253-261.

11. Fazel S, Cimini M, Chen L, Li S, Angoulvant D, Fedak P, Verma S, Weisel RD, Keating A, Li RK: Cardioprotective c-kit + cells are from the bone marrow and regulate the myocardial balance of angiogenic cytokines. J Clin Invest 2006, 116:1865-1877.

12. Martin-Rendon E, Brunskill SJ, Hyde CJ, Stanworth SJ, Mathur A, Watt SM: Autologous bone marrow stem cells to treat acute myocardial infarction: a systematic review. Eur Heart J 2008, 29:1807-1818.

13. Santos JM, Barcia RN, Simoes SI, Gaspar MM, Calado S, Agua-Doce A, Almeida SC, Almeida J, Filipe M, Teixeira M, Martins JP, Graça L, Cruz MEM, Cruz $\mathrm{P}, \mathrm{Cruz} \mathrm{H}$ : The role of human umbilical cord tissue-derived mesenchymal stromal cells $\left(U C X^{\oplus}(\mathrm{R})\right)$ in the treatment of inflammatory arthritis. J Trans/ Med 2013, 11:18.

14. Psaltis PJ, Zannettino AC, Worthley SG, Gronthos S: Concise review: mesenchymal stromal cells: potential for cardiovascular repair. Stem Cells 2008, 26:2201-2210.

15. Ohnishi S, Nagaya N: Prepare cells to repair the heart: mesenchymal stem cells for the treatment of heart failure. Am J Nephrol 2007, 27:301-307.

16. Schuleri $\mathrm{KH}$, Boyle AJ, Hare JM: Mesenchymal stem cells for cardiac regenerative therapy. Handb Exp Pharmacol 2007, 180:195-218.

17. Wen Z, Zheng S, Zhou C, Wang J, Wang T: Repair mechanisms of bone marrow mesenchymal stem cells in myocardial infarction. $J$ Cell Mol Med 2011, 15:1032-1043.

18. Cashman TJ, Gouon-Evans V, Costa KD: Mesenchymal stem cells for cardiac therapy: practical challenges and potential mechanisms. Stem Cell Rev 2013, 9:254-265.

19. Chen SL, Fang WW, Ye F, Liu YH, Qian J, Shan SJ, Zhang JJ, Chunhua RZ, Liao LM, Lin S, Sun JP: Effect on left ventricular function of intracoronary transplantation of autologous bone marrow mesenchymal stem cell in patients with acute myocardial infarction. Am J Cardiol 2004, 94:92-95.

20. Wang CC, Chen CH, Lin WW, Hwang SM, Hsieh PC, Lai PH, Yeh YC, Chang Y, Sung HW: Direct intramyocardial injection of mesenchymal stem cell sheet fragments improves cardiac functions after infarction. Cardiovasc Res 2008, 77:515-524.

21. Amado LC, Saliaris AP, Schuleri KH, St John M, Xie JS, Cattaneo S, Durand DJ, Fitton T, Kuang JQ, Stewart G, Lehrke S, Baumgartner WW, Martin BJ, Heldman AW, Hare JM: Cardiac repair with intramyocardial injection of allogeneic mesenchymal stem cells after myocardial infarction. Proc Natl Acad Sci U S A 2005, 102:11474-11479.

22. Wang YQ, Wang M, Zhang P, Song JJ, Li YP, Hou SH, Huang CX: Effect of transplanted mesenchymal stem cells from rats of different ages on the improvement of heart function after acute myocardial infarction. Chin Med J (Engl) 2008, 121:2290-2298.

23. Latifpour M, Nematollahi-Mahani SN, Deilamy M, Azimzadeh BS, Eftekhar-Vaghefi SH, Nabipour F, Najafipour H, Nakhaee N, Yaghoubi M, Eftekhar-Vaghefi R,

Nabipour F, Najafipour H, Nakhaee N, Yaghoubi M, Eftekhar-Vaghefi R, Salehinejad $\mathrm{P}$, Azizi $\mathrm{H}$ : Improvement in cardiac function following transplantation of human umbilical cord matrix-derived mesenchymal cells. Cardiology 2011, 120:9-18.

24. Otto Beitnes J, Oie E, Shahdadfar A, Karlsen T, Muller RM, Aakhus S, Reinholt FP, Brinchmann JE: Intramyocardial injections of human mesenchymal stem cells following acute myocardial infarction modulate scar formation and improve left ventricular function. Cell Transplant 2012, 21:1697-1709.

25. Tang J, Xie Q, Pan G, Wang J, Wang M: Mesenchymal stem cells participate in angiogenesis and improve heart function in rat model of myocardial ischemia with reperfusion. Eur J Cardiothorac Surg 2006, 30:353-361.

26. Xie XJ, Wang JA, Cao J, Zhang X: Differentiation of bone marrow mesenchymal stem cells induced by myocardial medium under hypoxic conditions. Acta Pharmacol Sin 2006, 27:1153-1158.

27. Toma C, Pittenger MF, Cahill KC, Byrne BJ, Kessler PD: Human mesenchymal stem cells differentiate to a cardiomyocyte phenotype in the adult murine heart. Circulation 2002, 105:93-98.

28. Kawada H, Fujita J, Kinjo K, Matsuzaki Y, Tsuma M, Miyatake H, Muguruma Y, Tsuboi K, Itabashi Y, Ikeda Y, Ogawa S, Okano H, Hotta T, Ando K, Fukuda K: Nonhematopoietic mesenchymal stem cells can be mobilized and differentiate into cardiomyocytes after myocardial infarction. Blood 2004, 104:3581-3587.

29. Quevedo HC, Hatzistergos KE, Oskouei BN, Feigenbaum GS, Rodriguez JE, Valdes D, Pattany PM, Zambrano JP, Hu Q, McNiece I, Heldman AW, Hare $J M$ : Allogeneic mesenchymal stem cells restore cardiac function in chronic ischemic cardiomyopathy via trilineage differentiating capacity. Proc Natl Acad Sci U S A 2009, 106:14022-14027.

30. Dayan V, Yannarelli G, Filomeno P, Keating A: Human mesenchymal stromal cells improve scar thickness without enhancing cardiac function in a chronic ischaemic heart failure model. Interact Cardiovasc Thorac Surg 2012, 14:516-520.

31. Ohnishi S, Sumiyoshi H, Kitamura S, Nagaya N: Mesenchymal stem cells attenuate cardiac fibroblast proliferation and collagen synthesis through paracrine actions. FEBS Lett 2007, 581:3961-3966.

32. Li L, Zhang $S$, Zhang $Y, Y u B, X u Y$, Guan Z: Paracrine actions mediate the antifibrotic effect of transplanted mesenchymal stem cells in a rat model of global heart failure. Mol Biol Rep 2009, 36:725-731.

33. Nagaya N, Fujii T, Iwase T, Ohgushi H, Itoh T, Uematsu M, Yamagishi M, Mori $H$, Kangawa K, Kitamura S: Intravenous administration of mesenchymal stem cells improves cardiac function in rats with acute myocardial infarction through angiogenesis and myogenesis. Am J Physiol Heart Circ Physiol 2004, 287:H2670-H2676.

34. Kinnaird T, Stabile E, Burnett MS, Shou M, Lee CW, Barr S, Fuchs S, Epstein SE: Local delivery of marrow-derived stromal cells augments collateral perfusion through paracrine mechanisms. Circulation 2004, 109:1543-1549.

35. Kinnaird T, Stabile E, Burnett MS, Lee CW, Barr S, Fuchs S, Epstein SE: Marrow-derived stromal cells express genes encoding a broad spectrum of arteriogenic cytokines and promote in vitro and in vivo arteriogenesis through paracrine mechanisms. Circ Res 2004, 94:678-685.

36. Shake JG, Gruber PJ, Baumgartner WA, Senechal G, Meyers J, Redmond JM, Pittenger MF, Martin BJ: Mesenchymal stem cell implantation in a swine myocardial infarct model: engraftment and functional effects. Ann Thorac Surg 2002, 73:1919-1926.

37. Burdon TJ, Paul A, Noiseux N, Prakash S, Shum-Tim D: Bone marrow stem cell derived paracrine factors for regenerative medicine: current perspectives and therapeutic potential. Bone Marrow Res 2011, 2011:207326.

38. Caplan Al, Dennis JE: Mesenchymal stem cells as trophic mediators. J Cell Biochem 2006, 98:1076-1084.

39. Gnecchi M, Zhang Z, Ni A, Dzau VJ: Paracrine mechanisms in adult stem cell signaling and therapy. Circ Res 2008, 103:1204-1219.

40. Shabbir A, Zisa D, Suzuki G, Lee T: Heart failure therapy mediated by the trophic activities of bone marrow mesenchymal stem cells: a noninvasive therapeutic regimen. Am J Physiol Heart Circ Physiol 2009, 296:H1888-H1897. 
41. Lopez Y, Lutjemeier B, Seshareddy K, Trevino EM, Hageman KS, Musch TI, Borgarelli M, Weiss ML: Wharton's jelly or bone marrow mesenchymal stromal cells improve cardiac function following myocardial infarction for more than 32 weeks in a rat model: a preliminary report. Curr Stem Cell Res Ther 2013, 8:46-59.

42. Zhang W, Liu XC, Yang L, Zhu DL, Zhang YD, Chen Y, Zhang HY: Wharton's jelly-derived mesenchymal stem cells promote myocardial regeneration and cardiac repair after miniswine acute myocardial infarction. Coron Artery Dis 2013, 24:549-558.

43. Corrao S, La Rocca G, Lo lacono M, Zummo G, Gerbino A, Farina F, Anzalone R: New frontiers in regenerative medicine in cardiology: the potential of Wharton's jelly mesenchymal stem cells. Curr Stem Cell Res Ther 2013, 8:39-45.

44. Santos J, Soares R, Martins J, Basto V, Coelho M, Cruz P, Cruz H: Isolation method of precursor cells from human umbilical cord. In Isolation method of precursor cells from human umbilical cord. Portugal: Medinfar, ECBio; 2008 [INPI ed., vol. 103843]

45. Tateishi K, Ashihara E, Takehara N, Nomura T, Honsho S, Nakagami T, Morikawa S, Takahashi T, Ueyama T, Matsubara H, Oh H: Clonally amplified cardiac stem cells are regulated by Sca-1 signaling for efficient cardiovascular regeneration. J Cell Sci 2007, 120:1791-1800.

46. Directive 2004/23/EC of the European parliament and of the council of 31 March 2004 on setting standards of quality and safety for the donation, procurement, testing, processing, preservation, storage and distribution of human tissues and cells. [http://eur-lex.europa.eu/ LexUriServ/LexUriServ.do?uri=OJ:L:2004:102:0048:0058:en:PDF]

47. Directive $2010 / 63 / E U$ of the European parliament and of the council of 22 September 2010 on the protection of animals used for scientific purposes. [http://eur-lex.europa.eu/LexUriServ/LexUriServ.do?uri=OJ: L:2010:276:0033:0079:en:PDF]

48. Guidance document on the recognition, assessment and use of clinical signs as human endpoints for experimental animals used in safety evaluation. [http://www.oecd-ilibrary.org/docserver/download/9750191e.pdf? expires $=1391474459 \& i d=i d \& a c c n a m e=$ quest\&checksum $=$ 9F73864A63C4779BB5ABBBCA6B5CDB5F]

49. Michael LH, Entman ML, Hartley CJ, Youker KA, Zhu J, Hall SR, Hawkins HK, Berens K, Ballantyne CM: Myocardial ischemia and reperfusion: a murine model. Am J Physiol 1995, 269:H2147-H2154.

50. Nascimento DS, Valente M, Esteves T, de Pina Mde F, Guedes JG, Freire A, Quelhas P, Pinto-do OP: MIQuant-semi-automation of infarct size assessment in models of cardiac ischemic injury. PLoS One 2011, 6:e25045.

51. Takagawa J, Zhang Y, Wong ML, Sievers RE, Kapasi NK, Wang Y, Yeghiazarians Y, Lee RJ, Grossman W, Springer ML: Myocardial infarct size measurement in the mouse chronic infarction model: comparison of area- and length-based approaches. J Appl Physiol 2007, 102:2104-2111.

52. Claycomb W, Lanson NJ, Stallworth B, Egeland D, Delcarpio J, Bahinski A, Izzo NJ: HL-1 cells: A cardiac muscle cell line that contracts and retains phenotypic characteristics of the adult cardiomyocyte. Proc Natl Acad Sci U S A 1998, 95:2979-2984.

53. Arnaoutova I, Kleinman HK: In vitro angiogenesis: endothelial cell tube formation on gelled basement membrane extract. Nat Protoc 2010, 5:628-635.

54. Dominici M, Le Blanc K, Mueller I, Slaper-Cortenbach I, Marini F, Krause D, Deans R, Keating A, Prockop D, Horwitz E: Minimal criteria for defining multipotent mesenchymal stromal cells: The International Society for Cellular Therapy position statement. Cytotherapy 2006, 8:315-317.

55. Bergmann O, Bhardwaj RD, Bernard S, Zdunek S, Barnabe-Heider F, Walsh S, Zupicich J, Alkass K, Buchholz BA, Druid H, Jovinge S, Frisén J: Evidence for cardiomyocyte renewal in humans. Science 2009, 324:98-102.

56. Schächinger V, Erbs S, Elsässer A, Haberbosch W, Hambrecht R, Hölschermann H, Yu J, Corti R, Mathey DG, Hamm CW, Süselbeck T, Assmus B, Tonn T, Dimmeler S, Zeiher AM, REPAIR-AMI Investigators: Intracoronary bone marrow-derived progenitor cells in acute myocardial infarction. N Engl J Med 2006, 355:1210-1221.

57. Assmus B, Honold J, Schächinger $V$, Britten MB, Fischer-Rasokat U, Lehmann R, Teupe C, Pistorius K, Martin H, Abolmaali ND, Tonn T, Dimmeler S, Zeiher AM: Transcoronary transplantation of progenitor cells after myocardial infarction. N Engl J Med 2006, 355:1222-1232.

58. Janssens S, Dubois C, Bogaert J, Theunissen K, Deroose C, Desmet W, Kalantzi M, Herbots L, Sinnaeve P, Dens J, Maertens J, Rademakers F, Dymarkowski S, Gheysens O, Van Cleemput J, Bormans G, Nuyts J, Belmans A, Mortelmans L,
Boogaerts M, Van de Werf F: Autologous bone marrow-derived stem-cell transfer in patients with ST-segment elevation myocardial infarction: double-blind, randomised controlled trial. Lancet 2006, 367:113-121.

59. Sürder D, Schwitter D, Moccetti T, Astori G, Rufibach K, Plein S, Lo-Cicero V, Soncin S, Windecker S, Moschovitis A, Wahl A, Erne P, Jamshidi P, Auf der Maur C, Manka R, Soldati G, Bühler I, Wyss C, Landmesser U, Lüscher TF, Corti R: Cell-based therapy for myocardial repair in patients with acute myocardial infarction: rationale and study design of the SWiss multicenter Intracoronary Stem cells Study in Acute Myocardial Infarction (SWISS-AMI). Am Heart J 2010, 160:58-64.

60. Lunde $K$, Solheim S, Aakhus S, Arnesen H, Abdelnoor M, Egeland T, Endresen K, llebekk A, Mangschau A, Fjeld JG, Smith HJ, Taraldsrud E, Grøgaard HK, Bjørnerheim R, Brekke M, Müller C, Hopp E, Ragnarsson A, Brinchmann JE, Forfang K: Intracoronary injection of mononuclear bone marrow cells in acute myocardial infarction. N Engl J Med 2006, 355:1199-1209.

61. Fukuhara S, Tomita S, Nakatani T, Ohtsu Y, Ishida M, Yutani C, Kitamura S: G-CSF promotes bone marrow cells to migrate into infarcted mice heart, and differentiate into cardiomyocytes. Cell Transplant 2004, 13:741-748.

62. Xiang MX, He AN, Wang JA, Gui C: Protective paracrine effect of mesenchymal stem cells on cardiomyocytes. J Zhejiang Univ Sci B 2009, 10:619-624.

63. Nakanishi C, Yamagishi M, Yamahara K, Hagino I, Mori H, Sawa Y, Yagihara T, Kitamura S, Nagaya N: Activation of cardiac progenitor cells through paracrine effects of mesenchymal stem cells. Biochem Biophys Res Commun 2008, 374:11-16.

64. Pagliari S, Romanazzo S, Mosqueira D, Pinto-do OP, Aoyagi T, Forte G: Adult stem cells and biocompatible scaffolds as smart drug delivery tools for cardiac tissue repair. Curr Med Chem 2013, 20:3429-3447.

65. Mangi AA, Noiseux N, Kong D, He H, Rezvani M, Ingwall JS, Dzau VJ: Mesenchymal stem cells modified with Akt prevent remodeling and restore performance of infarcted hearts. Nat Med 2003, 9:1195-1201.

\section{doi:10.1186/scrt394}

Cite this article as: Nascimento et al:: Human umbilical cord tissue-derived mesenchymal stromal cells attenuate remodeling after myocardial infarction by proangiogenic, antiapoptotic, and endogenous cell-activation mechanisms. Stem Cell Research \& Therapy 2014 5:5.

\section{Submit your next manuscript to BioMed Central and take full advantage of:}

- Convenient online submission

- Thorough peer review

- No space constraints or color figure charges

- Immediate publication on acceptance

- Inclusion in PubMed, CAS, Scopus and Google Scholar

- Research which is freely available for redistribution

Submit your manuscript at www.biomedcentral.com/submit
C Biomed Central 